\title{
Poverty Alleviation Strategy Policy Formulation in Toba Regency, North Sumatra Province
}

\author{
Marlan Hutahaean \\ Associate Professor at Master of Administrative Science, Post Graduate Program, \\ Universitas HKBP Nommensen, Medan. \\ Dimpos Manalu \\ Lecturer at Master of Administrative Science, Post Graduate Program, Universitas HKBP Nommensen, Medan. \\ Johnson Pasaribu \\ Lecturer at Master of Administrative Science, Post Graduate Program, Universitas HKBP Nommensen, Medan.
}

\begin{abstract}
This paper aims to uncover the process of public policies formulation, specifically regarding poverty reduction strategies and social protection in Toba Regency, North Sumatra. The poverty reduction policy that is the focus of this research consists of three Regional Regulations (Perda), which were only issued in 2019, after the district was established (autonomy) since 1999, namely: Regional Regulation No. 2/2019 concerning the Implementation of Social Welfare, Regional Regulation No. 10/2019 concerning Protection and Fulfillment of the Rights of Persons with Disabilities, and Regional Regulation Number 11/2019 concerning the Implementation of Elderly Welfare. This qualitative research concludes that the process and formulation of poverty reduction policies in Toba Regency took place technocratically and elitist. First, the three Regional Regulations are considered as "derived regulations", the operationalization of a higher level of statutory regulation (in this case government laws and regulations), which are considered to have clear scope and conception. Secondly, the three regional regulations were drafted at the end of the government (executive) period and national legislative elections which have implications and the potential for ineffective implementation of policies and as well as minimal oversight of the legislative majority which is not elected in the next period. This factor caused suspicion towards the three Regional Regulations to be solely formulated for the pragmatic interests of the incumbent regents for the sake of popularity and electability in the next regional elections. Third, there is a lack of public participation because these three regional regulations have policy targets for socially, culturally and politically vulnerable and voiceless groups, as well as the lack of support from civil society organizations. Based on the findings above, the policy recommendation put forward is that public involvement in the process and formulation of this Perda is not merely administrative in nature, but an active sequence from the setting agenda to the formulation.
\end{abstract}

\section{Keywords:}

policy formulation; social protection; welfare; disability; elderly welfare 


\section{Introduction}

This paper wants to reveal how the process and formulation of poverty reduction strategy policies in Toba District (previously known as Toba Samosir). The focus of the research discusses how decision makers, both technocratically ${ }^{11}$ and politically ${ }^{12}$, formulate public policies in the form of local regulations related to poverty reduction strategies ${ }^{13}$. In the policy-making process, did the government and the Local Legislative (DPRD) of Toba Regency involve community participation or deliberative policy ${ }^{14}$. The research focus is in Toba Regency on the grounds that because this district is a new district not in the era of reform or decentralization, it is hoped that the process and formulation of regional policies on poverty reduction will be more advanced. The assumption is that the government and the DPRD of Toba Regency are more experienced, so it is hoped that in any regional policy making, it is oriented towards the public interest and involves public participation. The argument to be built in this research is, "the policy-making process in the form of regional regulations, local government and the DPRD of Toba Regency is more guided by existing legislative policies, is not oriented towards the public interest, and minimal involves public participation, both at the technocratic level and political level."

Why choose the case process and policy formulation in the form of regional regulations on poverty reduction? There are at least three reasons for choosing this. First, the poverty reduction policy in this area is a non-routine policy. This means that this policy is made according to its interests - meaning that it is not formulated every year. ${ }^{15}$ Second, this policy is a regional policy that has a direct impact on the public, so it is necessary to study more deeply the role of the public in the making process. Logically, the public as a policy target must be involved in the regional policy-making process. Third, in public policy studies, there are various stages, namely agenda setting, policy formulation, policy making, policy implementation, policy evaluation, and policy change. Research on policy implementation

\footnotetext{
${ }^{11}$ It is a process and formulation of a draft poverty reduction strategy policy in the local government of Toba Regency.

${ }^{12}$ It is a process, discussion and policy setting in the Toba Regency DPRD.

${ }^{13}$ One form of public policy. There are at least 10 different uses of public policy terms (Hogwood and Gun, 1986 in Parson, 2005).

${ }_{14}$ The involvement of the community is very necessary so that in the implementation process, the public who is the target affected by the policy can convey various desires that need to be regulated in the regional policy that is being formulated.

15 Another form of policy is routine policies, namely policies formulated every year. For example, regional regulations on the Regional Revenue and Expenditure Budget (APBD).
} 
and evaluation has been done a lot, on the other hand, research on the process of formulating or making public policies is still very rare. Research conducted by Wibawa (1992) reveals that the process of making public policy in Indonesia is still focused on the executive or technocratic realm. His research focus is limited to how vertical and autonomous agencies formulate policies. The research has not yet reached its discussion at the DPRD or at the political level. Meanwhile, Hutahaean's (2013) research discusses policy making between the city government and Pematangsiantar DPRD regarding the Regional Revenue and Expenditure Budget (APBD, but the focus is on the dynamics of the formation of a divided or unified government. In addition, the cases raised are about routine policies), namely the APBD which is annually discussed and determined through regional policies.

The process of making public policy is not a simple matter, because it involves many actors and is often accompanied by a variety of interests. These differences in interests are often influenced by values. These values often influence the attitudes and behavior of actors. There are actors who want that the focus of policy is directed at increasing human resources, but there are also those who emphasize increasing infrastructure development. Or there are those who want economic growth, on the other hand there are those who want an even distribution of income.

Anderson (1979: 9), states, that "policy-making typically involves a pattern of action, extending over time and involving many decisions, some routine and some not so routine." This view would like to state that policy-making that involves various patterns of action and decisions applies to both routine and non-routine policies. Routine policies are policies that each year must be drawn up and discussed jointly between the executive and legislative branches. The State Revenue and Expenditure Budget (APBN) and Regional Revenue and Expenditure Budget (APBD) are examples of routine policies. Meanwhile, non-routine policies are policies that are jointly formulated and discussed between the executive and legislative branches based on their needs and interests. Even if this policy is discussed again later, it is usually a revision of several articles or paragraphs which are adjusted to the existing conditions. Revisions to non-routine policies are usually carried out within a certain period of the year.

Furthermore, Lindblom (1980: 2) provides the best way of understanding who and how to make policies. According to him, "one thing that must be understood is the 
characteristics of those who participate, what roles they play, what authority and power they have, and how to agree with and supervise one another." Furthermore, Lindblom (1980: 2-3), says that, "various kinds of participants, each playing different roles such as community groups (ordinary citizens), leaders of interest groups, legislators, legislative leaders, party activists, party leaders, judges (judges), public servants, technical experts, and business managers. "

At some level, policy is a political decision. It can even be said that the product of every political system is a policy. Lester and Stewart (2000: 29) even state that public policy-making is often seen as a conveyor belt, namely that issues are recognized first as problems and in the process of making them cannot be separated from the political process. As a political decision, ideally, policies are produced jointly by the executive and legislative branches. At the national level the public policy is in the form of a law (UU), while at the regional level it is a regional regulation (Perda). If the products of this public policy are in the form of laws and regional regulations, then it needs to get legitimacy from the legislature which is the people's representation.

Furthermore, one way to find out how policy makers formulate and determine policies is through a policy model approach. Policy models can clearly identify the reasons behind them, what are the bases, and how they formulate public policies. The elite model is an abstractation of a policy process in which public policy can be said to be identical with the perception of the political elite. In this model, the elites who are a small part have the function of regulating larger groups of society. Usually, various issues on the policy agenda are strongly influenced by the agreement or the outcome of conflict between elites. Meanwhile, the conflict itself is not a reflection of the will of the people. It is very difficult for the community to influence the elite to change the issues they have made into the policy agenda.

This model also suggests that elites usually want to maintain the status quo. It is realized that the elites, however, still pay attention to the needs of the community in making any policies. Because, at a certain level, they really need community support. The problem is, the fate and welfare of society seems to depend on the will of the elite and not in the hands of the society itself.

On the other hand, poverty is a problem faced by all countries. Even in developed countries such as the United States and Japan, although they are different in size than in 
developing countries, there is also poverty. Sharp et.al. (1996) as quoted by Kuncoro (2004: 141) states that: "Poverty amidst plenty" is a striking feature of the American scene. Our nation is the richest in the world, yet millions of the people are poor, and million that do not live in poverty are poor relative to others. This is not American dream; it is the American paradox. "

Ragnar Nurkse, as quoted by Moeljarto (1995: 25), further said that a poor country is poor, because he is poor. (a poor country is poor because it is poor). This view became known as the vicious circle of poverty theory. This is visualized in Figure 1 below.

Figure 1

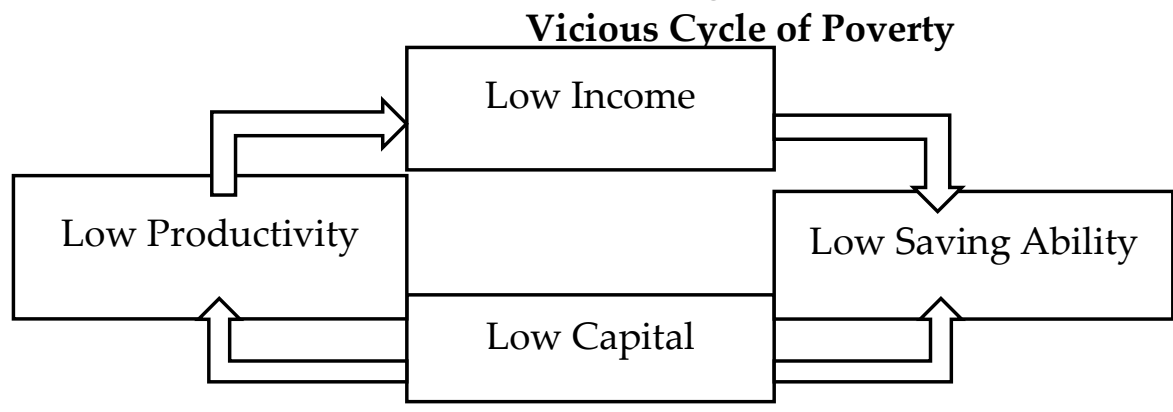

Source: Moeljarto (1995)

Meanwhile, Jazairy et.al. (1992: 69-87) suggests 10 factors that cause poverty, especially in rural areas. The ten factors are: (1) policy induced processes, (2) socio economic dualism, (3) population growth, (4) resource management and the environment, (5) natural cycles and processes, (6) the marginalization of women, (7) cultural and ethnic factors, (8) exploitative inter mediation, (9) internal political fragmentation and civil strife, and (10) international processes.

Judging from the poverty rate, the percentage of poverty level in Toba Regency is indeed above the national average. When the Government published its success in reducing the poverty rate to one digit $(9.66 \%)$ in 2018 , the poverty rate in Toba had actually reached one point $(8.67 \%)$ below it. However, this poverty rate is still relatively high, especially when compared to other districts in North Sumatra Province, such as Dairi (8.2\%), Serdang Bedagai (8.2\%), and Padang Lawas (8.4\%). ) (sumut.bps.go.id).

Table 1.

Number and Percentage of Poor PeoplevToba Regency 2004-2018 and Indonesia 2004-2019

\begin{tabular}{cccc} 
Year & Number (000) & State Percentage (\%) & $\begin{array}{c}\text { National Percentage } \\
\mathbf{( \% )}\end{array}$ \\
\hline 2004 & 58,40 & 19,21 & 16,66 \\
2005 & 30,80 & 18.99 & 15,97 \\
2006 & 30,18 & 17,85 & 17,75 \\
\hline
\end{tabular}




\begin{tabular}{lccc}
\hline 2007 & 25,60 & 15,28 & 16,58 \\
2008 & 19,78 & 11,62 & 15,42 \\
2009 & 17,34 & 10,07 & 14,15 \\
2010 & 17,60 & 10,15 & 13,33 \\
2011 & 16,93 & 9,67 & 12,36 \\
2012 & 16,64 & 9,43 & 11,66 \\
2013 & 16,96 & 9,54 & 11,46 \\
2014 & 16,51 & 9,23 & 10,96 \\
2015 & 18,31 & 10,21 & 11,13 \\
2016 & 18,20 & 10,08 & 10,70 \\
2017 & 18,49 & 10,19 & 10,12 \\
2018 & 15,82 & 8,67 & 9,66 \\
2019 & - & - & 9,41 \\
\hline
\end{tabular}

Source: Toba Regency in Figure 2020, p. 205.

https://www.bps.go.id/website/materi_ind/materiBrsInd-20200115120531.pdf, Access May, 242020.

The importance of a policy in obtaining legitimacy from the legislature is that the substance of the policy is truly in favor of the public interest. As representatives of the people, members of the legislature are obliged to bridge various interests of the people and voice them to the executive. Especially if the policies to be made intersect with the public interest.

In the context of the process and formulation of regional policies on poverty alleviation, policy actors, both those from the government and those from the DPRD, have different values, interests and goals. There is a pure goal of how to solve the problem of poverty properly. On the other hand, there are also those that aim not at the stated interests, but only to fulfill the assessment that they have produced regional policies even though their content is far from expectations and difficult to implement.

Another problem that arises in the regional policy-making process is the lack of public participation. Stakeholders, especially local governments and DPRDs are too rigid, that is, they only guide the regional policy-making process as stipulated in laws and regulations. They lack the courage to make breakthroughs by involving public participation from the start of the formulation process in the local government and the deliberation process in the DPRD. Thus, there is a tendency that the regional policy-making process is elitist.

Based on the above problems, the research questions in this paper are 1) What is the process of formulating the poverty reduction strategy policy in Toba Regency? 2) Did the local government and DPRD Toba Regency provide space for public participation in the 
formulation process? 3) If yes, how is the participation space carried out? 4) If not, what were the factors causing it?

\section{Methods}

The method is a method used by researchers to collect and analyze data in order to test or answer research questions that have been formulated previously. The choice of method is closely related to the type of data and the objectives desired by the researcher and the scope of the study. This research, which wants to see the link between decentralization policies and poverty reduction, uses secondary data obtained through various documents such as books, journals, previous research results, websites, and regional success stories that have succeeded in reducing poverty. In line with that, this research uses qualitative methods. Cresswell (2009: 4) states that the qualitative research method is "methods to explore and understand the meaning-by individuals or group of people-ascribed to social problems or humanity."

The data collected in this study, then be analyzed with descriptive analysis. By this technique it will be illustrated throughout the data or facts obtained from the field by applying the following procedure:

a. Using descriptive analysis to develop categories that are relevant to the purpose of research.

b. Interpretation of the results of descriptive analysis is done by referring to the data and theories accordingly.

Specifically, the data analysis done by the following steps:

1. The various data are grouped according to the main objectives to be achieved, especially the formulation of poverty reduction strategy policies in Toba district.

2. Next explains how to submit poverty reduction policy proposals in Toba district.

3. Furthermore, the discussion process for draft regional regulations related to poverty reduction at the political level in the Local Legislative is explained.

4. Finally, to draw conclusions about whether the public participates in the formulation of poverty reduction policies, it will be explained through the process of formulating the tatar-technocratic level and the process of discussing it at the political level. Based on this explanation, in the end it will be concluded whether the process of formulating the poverty alleviation strategy policy in Toba district uses a deliberative model or 
public involvement, or does it use an elite model. This means that the local government and legislative elites have played a very important role in the formulation.

\section{Results and Discussion}

\section{Formulation of Public Policy on Poverty and Social Welfare in Toba Regency}

This paper concludes that the formulation of policies in the form of three regional regulations (Perda) related to poverty (Perda on Social Welfare, Perda on Disalibity, Perda on Elderly) issued at the end of 2019 in Toba District was technocratic and elitist, with minimal public participation, and - in contrast to the theoretical assumptions which presuppose there is a tug of war and dynamic - in the process there is no struggle and tension between the parties concerned, especially the target groups who are the target of the Perda and other stakeholders.

It is called technocratic because the draft Perda originates from the executive (Dinas Sosial) as a derivative regional regulation where higher laws and government regulations with the same nomenclature have been issued beforehand. The formulation of this kind of Perda usually does not experience serious obstacles or challenges, compared to Perda-perda which arise as the specific and specific needs of a region. The formulation is also called elitist because this policy formulation process only takes place in a limited manner among the bureaucratic elite and the DPRD, without involving representatives of vulnerable social groups who are the target groups. These provisions regarding public participation can be fulfilled but are only administrative and legal formal. Community social groups and civil society organizations (CSOs) that are active in various issues of poverty, welfare, and social protection in the Toba region were not included.

The head of the Toba District Social Service, Dr. Rajaipan Sinurat, revealed that the motivation or background for the submission of these three Perda by his agency was to increase the leverage of the APBD budget against OPDs or their offices, in particular the increasing need to respond to the three issues (social welfare, disabilities, and the elderly) where so far there has been no legal umbrella. He admitted that the availability of funds at the Dinas was very small, the Perda also did not exist, so that the agency experienced difficulties when, for example, a number of social issues such as the increase in beggars and homeless people had increased in this district in recent years. However, he admitted, until the 
budget for the following year after this regional regulation was passed, the required budget could not be realized due to the outbreak of the Corona virus (Covid-19) which forced central and regional budgets to focus on handling this global pandemic. ${ }^{16}$

In addition, usually derivative regional regulations no longer require debate, receive minimal input from the public, including input from the legislature, because all basic considerations, references, concepts, indicators, measures, and other important matters have been clearly provided in the higher regulation. Derivative regulations usually only follow existing provisions, so that the formulation process tends to be a formality and ratification. The process and context of formulation at the level of laws and government regulations are considered to be in-depth and sufficient, so that in the formulation of derivative regional regulations of this kind, laws and government regulations are considered "given".

Local regulation (Perda) Number 2 of 2019 concerning the Implementation of Social Welfare (enacted May 6, 2019) is a derivative regional regulation (Perda derivative) of Law Number 11 of 2009 concerning Social Welfare, which is also regulated in Government Regulation Number 39 of 2012 concerning the Implementation of Social Welfare. Perda Number 10 of 2019 concerning Protection and Fulfillment of the Rights of Persons with Disabilities (stipulated 28 November 2019) is a derivative of Law Number 8 of 2016 concerning Persons with Disabilities and Government Regulation Number 70 of 2019 concerning Planning, Implementation, Evaluation of Respect, Protection and Fulfillment Rights of Persons with Disabilities, which was passed on Friday, 11 October 2019.17 Regional Regulation Number 11 of 2019 concerning the Implementation of Elderly Welfare (enacted 28 November 2019) is a derivative of Law Number 13 of 1998 concerning Elderly Welfare and Government Regulation Number 43 of 2004 regarding the Implementation of Efforts to Improve the Welfare of the Elderly.

More details regarding the basic considerations, aims and objectives, as well as the target groups of the three Regional Regulations above, can be seen in table 2 below.

Table 2.

The Main Provisions in the Three Regional Regulations of Toba Regency concerning Social Welfare

\footnotetext{
${ }^{16}$ Interview with Rajaipan Sinurat, Head of Social Affairs Office of Toba Regency, at the Regent's Office, Balige, May 9, 2020.

17 See https://difabel.tempo.co/read/1259756/pp-pedoman-pemenuhan-hak-penyandang-disabilitas-sudahdiketok/full\&view=ok, accessed on 31 May 2020.
} 


\begin{tabular}{|c|c|c|c|c|}
\hline & Product of Lawa & Basic Consideration & Objectives and Goals & Target Group \\
\hline 1 & $\begin{array}{l}\text { Local Regulation } \\
\text { Number } 2 \text { of } 2019 \\
\text { concerning the } \\
\text { Implementation of } \\
\text { Social Welfare } \\
\text { (enacted May 6, } \\
\text { 2019). }\end{array}$ & $\begin{array}{l}\text { To protect the } \\
\text { entire community, } \\
\text { promote public } \\
\text { welfare and } \\
\text { achieve social } \\
\text { justice, it is } \\
\text { necessary to carry } \\
\text { out social welfare; } \\
\text { In order to } \\
\text { improve services } \\
\text { for social welfare } \\
\text { issues, it needs to } \\
\text { be implemented in } \\
\text { a planned, directed } \\
\text { and sustainable } \\
\text { manner; } \\
\text { In implementing } \\
\text { Social Welfare } \\
\text { issues } \\
\text { simultaneously, a } \\
\text { juridical basis is } \\
\text { required for the } \\
\text { region as a } \\
\text { guideline for the } \\
\text { implementation } \\
\text { and handling of } \\
\text { people with social } \\
\text { welfare problems. }\end{array}$ & $\begin{array}{l}\text { - The purpose of the } \\
\text { implementation of social } \\
\text { welfare is to ensure the } \\
\text { implementation of social } \\
\text { welfare in a directed, } \\
\text { integrated and } \\
\text { sustainable manner, } \\
\text { which is carried out by } \\
\text { the Regional } \\
\text { Government and the } \\
\text { community according to } \\
\text { their authorities based } \\
\text { on the provisions of } \\
\text { laws and regulations. } \\
\text { - Implementation of } \\
\text { social welfare aims to: } \\
\text { (a) Increase the level of } \\
\text { welfare, quality and } \\
\text { survival; (b) Restoring } \\
\text { social functions in order } \\
\text { to achieve } \\
\text { independence; (c) } \\
\text { Increase the social } \\
\text { resilience of the } \\
\text { community in } \\
\text { preventing and dealing } \\
\text { with social welfare } \\
\text { problems; (d) Increasing } \\
\text { the capacity, concern } \\
\text { and social responsibility } \\
\text { of the business world } \\
\text { and the community in } \\
\text { organizing social } \\
\text { welfare in an } \\
\text { institutional and } \\
\text { sustainable manner; (e) } \\
\text { Improve the quality of } \\
\text { management of social } \\
\text { welfare administration. }\end{array}$ & $\begin{array}{l}\text { - Persons with } \\
\text { Social Welfare } \\
\text { Problems (PMKS): } \\
\text { Family: the house } \\
\text { is not suitable for } \\
\text { habitation; socio- } \\
\text { economic } \\
\text { vulnerability; } \\
\text { social } \\
\text { psychological } \\
\text { problems; The } \\
\text { poor; victims of } \\
\text { social disasters. } \\
\text { Children: } \\
\text { neglected toddlers; } \\
\text { homeless child; } \\
\text { Street children; } \\
\text { brat; children with } \\
\text { disabilities; } \\
\text { children with legal } \\
\text { needs; children in } \\
\text { conflict with the } \\
\text { law; child victims } \\
\text { of criminal acts, } \\
\text { and or; child } \\
\text { witness of a crime. } \\
\text { Women: socio- } \\
\text { homeless; beggar; } \\
\text { displaced people; } \\
\text { economic } \\
\text { vulnerable, and / } \\
\text { or; victims of } \\
\text { violence. } \\
\text { Elderly: neglected; } \\
\text { intellectuals; } \\
\text { disabilities; the } \\
\text { poor, and / or; } \\
\text { victims of } \\
\text { violence. } \\
\text { - }\end{array}$ \\
\hline
\end{tabular}




\begin{tabular}{|c|c|c|c|c|}
\hline & Product of Lawa & Basic Consideration & Objectives and Goals & Target Group \\
\hline \multirow[b]{2}{*}{2} & & & & $\begin{array}{l}\text { victims of drug } \\
\text { abuse; former } \\
\text { convicts; people } \\
\text { living with HIV / } \\
\text { AIDS (PLWHA); } \\
\text { chronic disease } \\
\text { scars, and or; } \\
\text { prostitute. }\end{array}$ \\
\hline & $\begin{array}{l}\text { Regional } \\
\text { Regulation } \\
\text { Number } 10 \text { of } 2019 \\
\text { concerning } \\
\text { Protection and } \\
\text { Fulfillment of } \\
\text { Rights of Persons } \\
\text { with Disabilities } \\
\text { (stipulated 28 } \\
\text { November 2019) }\end{array}$ & $\begin{array}{l}\text { Persons with } \\
\text { disabilities are part } \\
\text { of citizens who } \\
\text { have equal rights } \\
\text { and obligations, } \\
\text { the same dignity } \\
\text { and status based } \\
\text { on the } 1945 \\
\text { Constitution of the } \\
\text { Unitary State of the } \\
\text { Republic of } \\
\text { Indonesia and have } \\
\text { recognition and } \\
\text { protection of } \\
\text { human rights and } \\
\text { guarantee equality } \\
\text { before the law; } \\
\text { The need for } \\
\text { understanding } \\
\text { both from the } \\
\text { community and } \\
\text { from local } \\
\text { government } \\
\text { officials about the } \\
\text { existence of } \\
\text { Persons with } \\
\text { Disabilities as part } \\
\text { of citizens, where } \\
\text { Persons with } \\
\text { Disabilities are } \\
\text { equated with sick } \\
\text { and helpless } \\
\text { people, so that the } \\
\text { thersons to }\end{array}$ & $\begin{array}{l}\text { - The purpose of this } \\
\text { Regional Regulation } \\
\text { is an effort by the } \\
\text { Regional } \\
\text { Government and } \\
\text { the community to } \\
\text { protect and fulfill } \\
\text { the rights of Persons } \\
\text { with Disabilities in } \\
\text { the Regions. } \\
\text { Protection and } \\
\text { Fulfillment of the } \\
\text { Rights of Persons } \\
\text { with Disabilities is } \\
\text { aimed at: (a) to fully } \\
\text { and equally respect, } \\
\text { promote, protect } \\
\text { and fulfill human } \\
\text { rights and basic } \\
\text { freedoms of Persons } \\
\text { with Disabilities; (b) } \\
\text { ensure the respect, } \\
\text { promotion, } \\
\text { protection and } \\
\text { fulfillment of the } \\
\text { rights inherent in } \\
\text { the dignity of } \\
\text { Persons with } \\
\text { Disabilities; (c) } \\
\text { realizing a higher } \\
\text { quality, fairer, } \\
\text { physically and } \\
\text { mentally }\end{array}$ & $\begin{array}{l}\text { Persons with } \\
\text { Disabilities, in the } \\
\text { General Provisions, } \\
\text { are stated as "every } \\
\text { person who } \\
\text { experiences physical, } \\
\text { intellectual, mental, } \\
\text { and / or sensory } \\
\text { limitations for a long } \\
\text { period of time who } \\
\text { interacts with the } \\
\text { environment may } \\
\text { experience obstacles } \\
\text { and difficulties to } \\
\text { participate fully and } \\
\text { effectively with other } \\
\text { citizens based on equal } \\
\text { rights". }\end{array}$ \\
\hline
\end{tabular}


Product of Lawa $\quad$ Basic Consideration $\quad$ Objectives and Goals $\quad$ Target Group

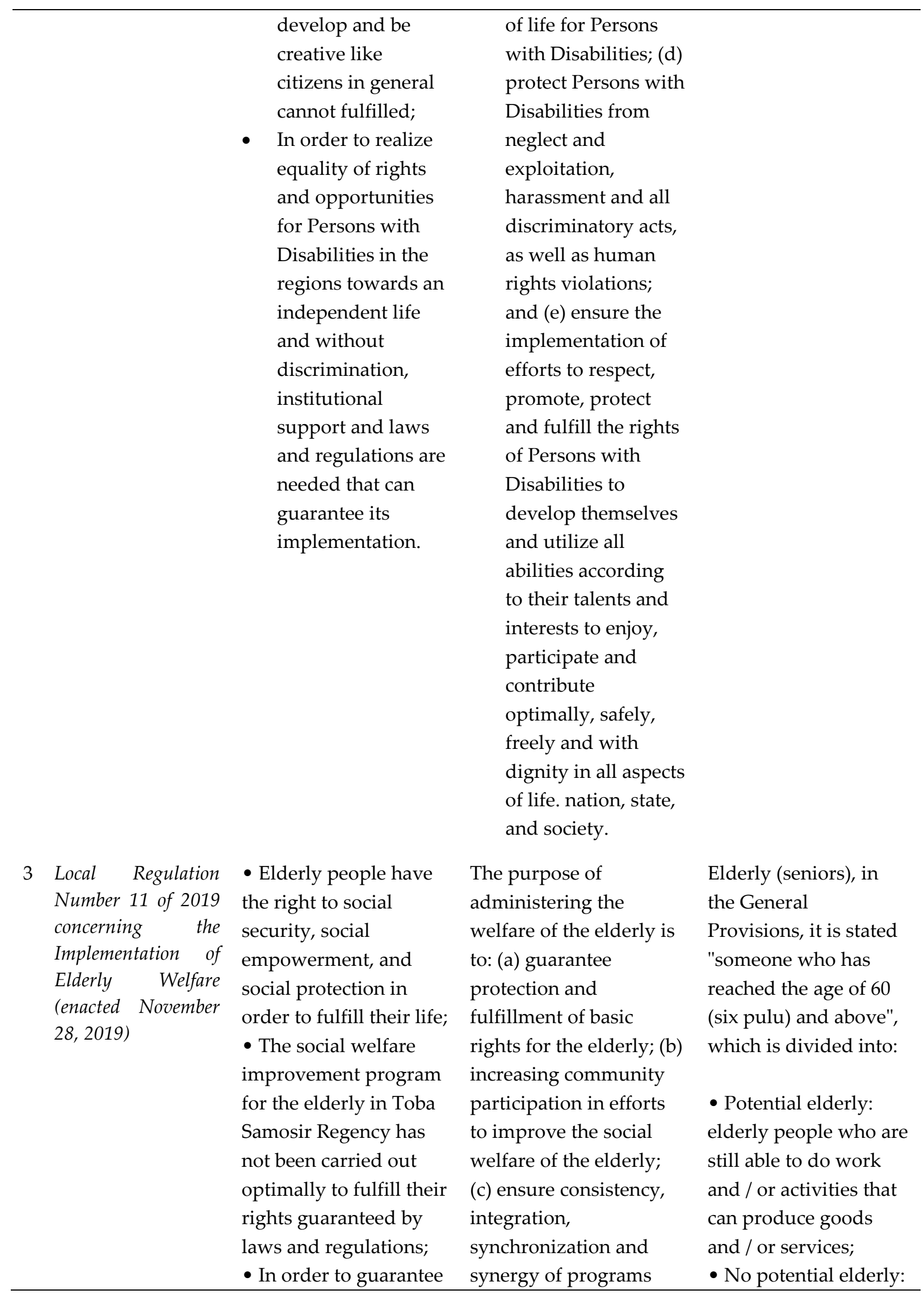




\begin{tabular}{|c|c|c|c|}
\hline Product of Lawa & Basic Consideration & Objectives and Goals & Target Group \\
\hline & $\begin{array}{l}\text { the fulfillment of the } \\
\text { rights of the elderly, it } \\
\text { is necessary to carry } \\
\text { out an integrated and } \\
\text { sustainable manner by } \\
\text { stipulating in the } \\
\text { Regional Regulation. }\end{array}$ & $\begin{array}{l}\text { and improvement of } \\
\text { social welfare for the } \\
\text { elderly; (d) extending } \\
\text { life expectancy, } \\
\text { increasing } \\
\text { independence and } \\
\text { productive life in the } \\
\text { elderly. }\end{array}$ & $\begin{array}{l}\text { elderly people who are } \\
\text { helpless to make a } \\
\text { living so that their } \\
\text { lives depend on the } \\
\text { help of others; } \\
\text { - Poor elderly: } \\
\text { someone who is } 60 \\
\text { (sixty) years of age and } \\
\text { over, does not have } \\
\text { provisions for life, } \\
\text { work and income; } \\
\text { - Abandoned elderly: } \\
\text { someone who is } 60 \\
\text { (sixty) years of age and } \\
\text { over, does not have } \\
\text { provisions for life, } \\
\text { work, income, or does } \\
\text { not even have relatives } \\
\text { who can meet their } \\
\text { basic needs. }\end{array}$ \\
\hline
\end{tabular}

Source: Processed from the Perda Document, 2020.

In the technocratic process of formulating or formulating Perda-perda, public participation tends to be minimal and almost neglected. The technocratic paradigm in the Weberian tradition, especially in the context of public policy formulation, presupposes that the bureaucracy is seen and sees itself as a rational, neutral, non-interest, impartial actor who stands above all interests. This is compounded by other factors such as a paternalistic culture, which considers the bureaucracy as the "father" and the community as "the child".

The choice of words used for these vulnerable groups as "people with social welfare problems" (PMKS) implicitly shows a biased perspective of the bureaucracy which tends to regard these vulnerable groups as "problems" (problems) and the programs launched in In these Perda-perda it is considered as "social assistance" rather than the "right" of the community group which is guaranteed in the constitution. Poverty also tends to be perceived as a weakness in the poor itself, such as lack of skills, laziness, indiscipline, or weak need for achievement. According to Ishak Salim, the term PMKS has long been a criticism of activists and academics with disabilities. In addition to placing the diffable as the object of social 
welfare problems, this terminology or disability-related policies makes the Ministry of Social Affairs the leading sector, where cross-sectoral affairs should be. ${ }^{18}$

This trend can be traced further into the paradigm of poverty policy makers in the regions, including in North Sumatra, namely a strong perception that blames people for being poor because they are stupid, lazy, lacking high achievement motivation, lack of skills, which in the end forgetting the structural factors and public policies that are the main causes of poverty. The survey on Governance and Decentralization (GDS 1) conducted by the UGM Center for Population and Policy Studies (PSKK) in 2002 concluded that policy makers in the regions, namely the local government (bureaucracy) and the DPRD tended to judge that poverty that occurred in the area was mainly due to weaknesses. Weaknesses found in poor people, namely due to low education and lack of hard work, lack of skills and skills, including heredity, namely because the poor actually come from a poor family. They do not see structural factors such as job opportunities, lack of budget for poverty alleviation programs, ineffective programs, and regulations that harm the poor as the main problems. Thus, this survey illustrates that, from the start, long before the poverty alleviation program was implemented, it could be predicted that the failure was due to the fact that in the minds, mind sets and paradigms of policy makers and stakeholders there was bias in viewing poverty.

In the context of the formulation of the three Regional Regulations, legally and formally, the process of formulating this public policy also follows the provisions in Law Number 12 of 2011 concerning the Formation of Laws and Regulations, which, among other things, requires public participation, but this is not done in a representative manner. Public participation tends to be minimal because these social groups with direct interests in issues of social welfare, disabilities and the elderly are socially and culturally vulnerable and politically voiceless and lack civil society organizations. strong supporters such as those of workers ', peasants', children's and women's organizations, which are common in cities and remote areas of the country. If anything, they tend to be excluded because of the persistent perception in the bureaucracy that they are "provocateurs" or "trouble makers".

Although in Toba District there is a social institution classified as large and legendary under the HKBP church organization, Panti Karya Hepata, which handles groups of people with disabilities, this institution admits that it is completely not involved and does not know

\footnotetext{
18 Sihakl Salim, online interview, June, $1^{\text {st }}, 2020$,
} 
the process of formulating the regional regulation on disabilities, the elderly and social welfare. . "There is no invitation to discuss drafts, hearings, outreach, or public consultations. We don't even know that these regional regulations already exist, "said Pdt Osten Matondang, Director of the Hepata Panti Karya. ${ }^{19}$

Meanwhile, KSPPM, is known as a CSO who is very active and leading in public policy advocacy in the Lake Toba area, as well as the Tano Batak Indigenous Peoples Alliance of the Archipelago (AMAN), admitting similar things, were not involved in the policy formulation process, including because the two institutions it may be assumed - and not always true - that it does not pay special attention to the issues set out in the three Perda. According to the staff of the Toba KSPPM Region, Iwan Bernando Samosir, SS, the KSPPM was not involved at all in the formulation process of these three regional regulations, including the stages up to the approval. "This is probably because the Toba Regency Government always views the existence of KSPPM as a 'provocateur', which is often expressed by the current Toba Regent, especially after KSPPM advocated for land cases between the Batak indigenous people in Sigapiton and BODT." He admitted, when the KSPPM asked the Head of the Social Service directly why there was no socialization about the three regional regulations and did not involve CSOs such as the KSPPM, the head of the service only replied diplomatically and on the grounds that he had forgotten to give an invitation. According to him, this concern of the district government is completely unfounded because the KSPPM is also a partner of the DPRD and the Toba Regency Government in making regional regulations on Indigenous Peoples in Toba, which were initiated by KSPPM itself and have now been passed which take a long time and process, starting from the drafting. by KSPPM, team formation, FDG, RDP, socialization and others. In Nando's view, the issuance of the three social protection regulations seems to show that the Toba Regency Government does not expect input from the public or elements of civil society. "So, we suspect, there is an interest behind the issuance of these regional regulations," he added. ${ }^{20}$

The head of the Indigenous Peoples Alliance of the Archipelago (AMAN) tano Batak, Roganda Simanjuntak, SS, also shared a similar sentiment. AMAN Tano Batak was never invited to the drafting and socialization process. According to him, the Toba Regency

\footnotetext{
${ }^{19}$ Interview with Pdt Osten Johnhenri Matondang, Director of Panti Karya Hepata, May, 31 2020.

${ }^{20}$ Online interview with Iwan Bernando Samosir, Staff of KSPPM Wilyah Toba, June, 1 ${ }^{\text {st }}, 2020$.
} 
Government is still not seriously paying attention to public participation. Even if there is a public consultation process, it tends to be done as a formality. Like the process of issuing the Perda on Indigenous Peoples recently, according to him, the district government only conducted one public consultation, but suddenly two weeks later the draft regional regulation was passed in a plenary session. AMAN Tano Batak, according to Roganda, is actually very supportive of the issuance of the three regional regulations, because it targets vulnerable groups in Toba Regency. However, the content / substance of the regional regulation has not been known to many parties due to the lack of socialization and publication since the drafting, discussion, approval, and public consultation. According to him, public participation is absolutely necessary so that the public can later monitor the implementation of this Perda because the three Perda will automatically use the public budget (APBD). "There should be a tiered consultation starting from the sub-district level to the regency level," he said.21

In addition, these three regional regulations were issued at the end of the term of office of the currently serving regent (2015-2020 period), not even long after the national legislative elections (7 April 2019) were held. On the one hand, the process of drafting this regional regulation cannot directly support, instead it becomes the support, vision and mission of the elected district head implemented during his administration. Since these perda were drafted at the end of the period, it is likely that all three of them could no longer be implemented by the incumbent district head, unless he was re-elected in the next pilkada. If the public issues or problems regulated in this Perda are strategic issues for his government, surely these perda will be born at the beginning of the period so that they can be implemented as soon as possible to keep campaign promises.

On the other hand, the preparation of the three regional regulations was also carried out after the national legislative elections, in which most members of the legislature were no longer elected. According to a member of Commission C of the Toba Regency DPRD for the 2014-2019 period, who was also re-elected for the 2019-2024 period, Fauzi Sirait, the drafting of a regional regulation at the end of this term seemed deliberate by the executive because many DPRD members were not re-elected, so that attention their response to the formulation process for these Perda-perda has been greatly reduced. In addition, at the end of the period, many DPRD members were more concerned with official travel than attending meetings to

\footnotetext{
${ }^{21}$ Online interview with the Chairman of BPH AMAN Tano Batak, Roganda Simanjuntak, SS, June, 1st, 2020.
} 
earn additional income. ${ }^{22}$ According to Fauzi, the purpose of drafting these welfare regulations is to provide a legal basis for increasing the budget for social assistance ahead of the direct regional head elections for the benefit and benefit of the incumbent regent candidate. He confirmed the statement from the Head of Social Affairs as quoted above, that the formulation of this Perda was intended to increase budget leverage. However, according to Fauzi, this budget increase is not purely related to increasing social protection as mandated in various laws and regulations, but as a pragmatic political interest to the regions in the context of direct regional elections. This is not surprising because a similar phenomenon is also found in various regions in Indonesia: the budget allocation for social assistance has increased rapidly in the lead-up to the national election events and direct regional elections. ${ }^{23}$

Collectively, the technocratic approach, lack of public participation, and weak legislative oversight have resulted in minimal conflict of interests and tensions between actors in the formulation of these perda, which makes their implementation ineffective even though these perda have been passed. From the point of view of issues and social groups with an interest in these Perda-perda, the government and legislature are seen as issues and groups that are less strategic with their interests. According to Fauzi's admission, the tough discussion of ranperda between the executive and the legislature, including community groups, is that the three local regulations target sources of regional revenue (PAD) such as tax rates, tower or billboard rentals, and so on. The reason is that DPRD members are very interested in the increase in PAD which largely determines the clusters of their salary levels. In addition, discussions on ranperda are also tough if they come from DPRD initiatives because this is a record of their achievements and productivity.

\footnotetext{
${ }^{22}$ Only 10 candidates for the incumbent Toba Regency legislature were re-elected. Interview with members of the Toba Regency DPRD, Fauzi Sirait, ST, Porsea, May 25, 2020.

23 See: https://nasional.tempo.co/read/243050/jelang-pilkada-dana-bantuan-sosial-tasikmalaya-meningkat; https://tirto.id/anggaran-bantuan-sosial-langganan-naik-saat-tahun-pemilu-dcdb; https://www.kppod.org/berita/view?id=425; $\quad$ https://www.cnbcindonesia.com/news/20190422174033-468067/sebelum-pilpres-pemerintah-sebar-bantuan-sosial-rp-37-t;

https://edukasi.kompas.com/read/2015/11/09/18010771/Dana.Bansos.yang.Meningkat.Jelang.Pilkada.Dikhawatirk an.Rawan.Politik.Uang; $\quad$ https://nasional.tempo.co/read/720635/dana-bansos-dan-hibah-meningkat-jelangpilkada; https://news.detik.com/berita/d-3759685/jelang-pilkada-serentak-kpk-ingatkan-inkumben-soal-danabansos; https://www.liputan6.com/news/read/2365846/kemendagri-akui-dana-bansos-selalu-meningkat-jelangpilkada; https://kumparan.com/kumparannews/dana-bansos-dan-hibah-rawan-diselewengkan-petahana-jelangpilkada; all access May, 31 ${ }^{\text {st }}, 2020$.
} 
Table 3.

Process and Participation and Contestation of Interests in the Formulation of Three Social Welfare Local Regulation

\begin{tabular}{|c|c|c|c|c|}
\hline $\begin{array}{l}\text { Name of Local } \\
\text { Regulation }\end{array}$ & $\begin{array}{l}\text { Process and } \\
\text { Engagement of } \\
\text { Stakeholders }\end{array}$ & $\begin{array}{l}\text { Parties } \\
\text { Involved }\end{array}$ & Form of Engagement & $\begin{array}{c}\text { Interest } \\
\text { Contestation }\end{array}$ \\
\hline $\begin{array}{l}\text { Local Regulation } \\
\text { Number } 2 \text { of } \\
2019 \text { concerning } \\
\text { the } \\
\text { Implementation } \\
\text { of Social Welfare } \\
\text { (enacted May 6, } \\
\text { 2019). }\end{array}$ & $\begin{array}{l}\text { The process of } \\
\text { formulating this } \\
\text { Perda emerged at } \\
\text { the initiative of } \\
\text { the Social } \\
\text { Service. In each } \\
\text { stage, Focused } \\
\text { Group } \\
\text { Discussion (FGD) } \\
\text { and seminars } \\
\text { were conducted } \\
\text { for outreach in } \\
\text { two sub-districts: } \\
\text { Balige District } \\
\text { and Siantar } \\
\text { Narumonda } \\
\text { District. }\end{array}$ & $\begin{array}{l}\text { Academics } \\
\text { from North } \\
\text { Sumatra } \\
\text { University } \\
\text { (USU) } \\
\text { Public } \\
\text { People of } \\
\text { the Press } \\
\text { Legislative }\end{array}$ & $\begin{array}{l}\text { Provide input related to } \\
\text { local regulations } \\
\text { Publication } \\
\text { Facilitator } \\
\text { As iniciator, facilitator and } \\
\text { local regulation certifier } \\
\text { Provide input related to } \\
\text { local regulations }\end{array}$ & $\begin{array}{l}\text { There is no } \\
\text { strong or } \\
\text { stressful } \\
\text { contestation } \\
\text { of interests by } \\
\text { the parties } \\
\text { (stakeholders) } \\
\text { in the making } \\
\text { of this Local } \\
\text { Regulation. }\end{array}$ \\
\hline $\begin{array}{l}\text { Regional } \\
\text { Regulation } \\
\text { Number } 10 \text { of } \\
2019 \text { concerning } \\
\text { Protection and } \\
\text { Fulfillment of } \\
\text { Rights of Persons } \\
\text { with Disabilities } \\
\text { (stipulated 28 } \\
\text { November 2019) }\end{array}$ & $\begin{array}{l}\text { The process of } \\
\text { formulating this } \\
\text { Perda emerged at } \\
\text { the initiative of } \\
\text { the Social } \\
\text { Service. In each } \\
\text { stage, a Focused } \\
\text { Group } \\
\text { Discussion (FGD) } \\
\text { and seminars } \\
\text { were conducted } \\
\text { for outreach. }\end{array}$ & $\begin{array}{l}\text { Academics } \\
\text { from North } \\
\text { Sumatra } \\
\text { University } \\
\text { (USU) } \\
\text { Public } \\
\text { People of } \\
\text { the Press } \\
\text { Legislative } \\
\text { Executive } \\
\text { Person with } \\
\text { Disabilities }\end{array}$ & $\begin{array}{l}\text { Provide input related to } \\
\text { local regulations } \\
\text { Publication } \\
\text { Facilitator } \\
\text { As iniciator, facilitator and } \\
\text { local regulation certifier } \\
\text { Provide input related to } \\
\text { local regulations }\end{array}$ & $\begin{array}{l}\text { There is no } \\
\text { strong or } \\
\text { stressful } \\
\text { contestation } \\
\text { of interests by } \\
\text { the parties } \\
\text { (stakeholders) } \\
\text { in the making } \\
\text { of this Local } \\
\text { Regulation. }\end{array}$ \\
\hline $\begin{array}{l}\text { Local Regulation } \\
\text { Number } 11 \text { of } \\
2019 \text { concerning } \\
\text { the } \\
\text { Implementation } \\
\text { of Elderly }\end{array}$ & $\begin{array}{l}\text { The process of } \\
\text { formulating this } \\
\text { Perda emerged at } \\
\text { the initiative of } \\
\text { the Social } \\
\text { Service. At each }\end{array}$ & $\begin{array}{l}\text { Academics } \\
\text { from North } \\
\text { Sumatra } \\
\text { University } \\
\text { (USU) }\end{array}$ & $\begin{array}{l}\text { Making Draft of Local } \\
\text { Regulation }\end{array}$ & $\begin{array}{l}\text { There is no } \\
\text { strong or } \\
\text { stressful } \\
\text { contestation } \\
\text { of interests by } \\
\text { the parties }\end{array}$ \\
\hline
\end{tabular}




\begin{tabular}{|c|c|c|c|c|}
\hline $\begin{array}{l}\text { Name of Local } \\
\text { Regulation }\end{array}$ & $\begin{array}{c}\text { Process and } \\
\text { Engagement of } \\
\text { Stakeholders }\end{array}$ & $\begin{array}{c}\text { Parties } \\
\text { Involved }\end{array}$ & Form of Engagement & $\begin{array}{c}\text { Interest } \\
\text { Contestation }\end{array}$ \\
\hline \multirow{6}{*}{$\begin{array}{l}\text { Welfare (enacted } \\
\text { November 28, } \\
\text { 2019) }\end{array}$} & stage, a Focused & Public & Provide input related to & (stakeholders) \\
\hline & Group & & local regulations & in the making \\
\hline & $\begin{array}{l}\text { Discussion } \\
\text { (FGD), Seminar }\end{array}$ & $\begin{array}{l}\text { People of } \\
\text { the Press }\end{array}$ & Publication & $\begin{array}{l}\text { of this Local } \\
\text { Regulation. }\end{array}$ \\
\hline & and outreach & Legislative & Facilitator & \\
\hline & were conducted. & Executive & $\begin{array}{l}\text { As iniciator, facilitator and } \\
\text { local regulation certifier }\end{array}$ & \\
\hline & & Elderly & $\begin{array}{l}\text { Provide input related to } \\
\text { local regulations }\end{array}$ & \\
\hline
\end{tabular}

Source: Interview with Head of Social Service, Toba Regency, dr Rajaipan Sinurat, at Balige, 20 March 2020.

\section{Poverty Alleviation, Social Protection, and Welfare Programs in Toba District}

Departing from the previous description, this research also found that Toba District did not yet have a poverty reduction and social protection strategy that was formulated in a comprehensive, participatory and sustainable manner. It is not surprising then that, as seen in relation to perceptions and perspectives on poverty, poverty alleviation programs are carried out sporadically and without a clear vision. There is no strategic plan in which the results can be measured and evaluated later. Among the various sporadic aid programs referred to, among others, are:

- Providing seeds and agricultural tools for farmers which are distributed through the Department of Agriculture;

- Providing medical expenses for poor people through the Health Office and in collaboration with the Social Service;

- Providing assistance in the style of weaving tools, threads, sewing machines for UKM groups through the Koperindag Office; and,

- Other assistance related to community development through related agencies.

In general, poverty alleviation programs only tend to participate in poverty alleviation and social protection programs implemented by the central government through programs sourced from the state budget such as the Prosperous Family Card (KKS) which includes the Prosperous Indonesia Card (KIS), the Smart Indonesia Card (KIP), The Family Hope Program (PKH), less prosperous rice (Rastra), and childbirth insurance (Jampersal). Meanwhile, the 
budget amount for PKH Tobasa through the Ministry of Social is Rp. 8,753,208,941 (2016), Rp. 7,619,240,000 (2017), Rp. 8,250,285,600 (2018), and Rp. 21,392,750,000 (2019).

Meanwhile, the social protection program budgeted from the Toba District APBD in 2019 is IDR 21,392,750,000 with 56,840 beneficiaries, while in 2020 the budget is IDR 4,306,800,000 with 4,075 beneficiaries. For Non-Cash Food assistance, the beneficiaries of the Tobasa APBD are: 8,335 families (2018) and 7,996 families (2019), while for joint business group (KUBE) assistance are 85 groups (2016), 30 groups (2018), and one group (2019) . For 2018, beneficiaries for health insurance sourced from the APBN, APBD-Provincial and Regency APBD are recipients of contribution assistance (PBI) from the APBN totaling 58,441 people, recipients of Contribution assistance (PBI) from the Provincial APBD totaling 3,315 people, recipients of contribution assistance (PBI) APBD-Kab as much as 3,000 0rang (class-3 at a price of Rp. 23,000 / month. In addition, the beneficiaries for renovating houses that are unfit for habitation in 2016-2019 from the APBD are 100 units (2016), 17 units (2017) ), 3 units (2018), and 11 units (2019)..$^{24}$

Thus, we can see how poverty alleviation, social protection and welfare programs in Toba District do not have a clear pattern and format. On closer inspection, welfare programs in the era of regional autonomy do have some good news as well as some bad news. There are regions that take advantage of regional autonomy policies to innovate public services that can be replicated (best practices), but not infrequently they also only take advantage of these policies in the context of pragmatic and short-term politics only. We have witnessed the many creation and innovation of welfare policies in the regions, which not only provide a record of failures, but also successes. In this context, the discourse on welfare presents a diverse and multidimensional face: it cannot be seen solely in a single and steady national framework, but as a specific and contextual pluralistic regime. In other words, in the era of reform and decentralization in Indonesia, understanding and interpreting a single and uniform welfare regime is a misleading conclusion.

However, we will also soon find a disappointing reality because in general the discourse on welfare is temporary, populist and unsustainable because it comes from the "good intentions" of the authorities, not the result of struggles and actions to seize rights (citizenship) from the side of society. Welfare programs in various fields such as education,

\footnotetext{
${ }^{24}$ Interview with Rajaipan Sinurat, Head of Social Affairs Office for Toba Regency, in Balige, March 20, 2020.
} 
health, and agriculture that were born without a democratic citizenship process will be vulnerable to change or end automatically if the regional head changes. We also see how various forms of welfare programs are carried out in various ways, without clear standards and targets. It tends to depend on the "good intentions" of the leader, or at best the political commitment of the regional head and the legislature. It is not surprising that in various regions, this kind of program only tends to be accessed by community groups close to the power in the regions in a clientelistic manner.

Instead of being interpreted as a manifestation of citizens' rights, welfare programs like this can easily slip into mere "political tools" of power. This kind of situation eventually gives rise to populist-style leaders, who are not impossible to climb to a higher power in the present and in the future. Clearly, the quality of public services depends on political "contestation" at the local level: the power of civil society forces local governments to improve their performance. The direct election system makes it possible for the public to "push forward" the promotion of public services; while politicians and local governments have an interest in maintaining "electability".

\section{Conclusion}

This paper reveals that the process and formulation of poverty alleviation policies in Toba District - which consists of three regional regulations included in this research: the Perda on Social Welfare, the Perda on Disability, and the Perda on Elderly - took place technocratically and elitistly. Technocraticism and elitism in the formulation of these three Perda occurs for several reasons: first, these three Perda are considered as "derivative Perda", the operationalization of a higher level statutory regulation (in this case government laws and regulations), has a clear scope and conception. Second, these three regional regulations were drafted at the end of the government (executive) period and in the national legislative elections which had implications and had the potential for ineffective policy implementation and minimal oversight from the legislature whose majority was not elected in the next period. This factor causes suspicion that the three regional regulations are solely formulated for the pragmatic interest of the incumbent regent for the sake of regional head elections for the next period. Third, the lack of public participation because these three regulations have policy targets for vulnerable groups socially, culturally and politically (voiceless), as well as the lack 
of support from civil society organizations. Public involvement in the process and formulation of these three regional regulations is strictly administrative in nature to fulfill mere formal legality. Thus, the policy formulation process does not reflect the aspects of public participation and control as well as the lack of contestation and compromise dynamics among strategic groups (deliberative policy). As a result, the effectiveness of implementing this policy in the future tends to be questioned. This situation can be concluded as a bad public policy formulation process (flawed policy process) and takes place in "dark" spaces (intransparent), which in turn has implications for the effectiveness of its implementation.

If traced further, this technocratic and elitist policy formulation process was caused by the persistence of perceptions among bureaucrats and public officials that these policies and bureaucracies themselves are rational, neutral, and impartial entities and institutions that are believed to do their "best" and are above the interests of all groups. This Weberian tradition of bureaucratic thought is still dominant in our bureaucracy. This is exacerbated by the persistence of a paternalistic culture that regards government as "government" and not "public servant", which tends to make citizens as "clients" (clientelism), not as sovereign citizens (citizenship). On the other hand, these perceptions and paradigms are not only possessed by the bureaucracy but are also still attached to the citizens, who perceive welfare and social protection programs as charity from the government, not rights protected in the constitution.

Based on the above conclusions, the policy recommendation put forward is that in the future the formulation of public policies (Perda) is carried out in an open and participatory manner, which not only receives comprehensive supervision and discussion from the Regional People's Representative Council and the public at large, but also oversight from Ministry of Home Affairs and Ministry of Law and Human Rights. The provisions in the formulation of regional regulations must be implemented in accordance with the provisions stipulated in law.

However, by realizing that local regulations and public policies in general are political products, it is the duty of civil society organizations (CSOs) and strategic community groups (stakeholders) to fight for and ensure the birth of public policies that are on their side without waiting for the state and bureaucracy to fulfill them. . Struggle, competition, contestation, and compromise are political necessities that occur in democracy and deliberative policy. 


\section{References}

Anderson, J. E. (1979). Public Policy Making. London: Nelson.

Creswell, J. W. (2010). Research Design : Pendekatan Kualitatif, Kuantitatif, dan Mixed. Edisi Ketiga, Cetakan ke-4. Yogyakarta: Pustaka Pelajar.

Dunn, W. N. (2004). Public Policy Analysis: An Introduction. $2^{\text {nd }}$ Ed. New Jersey: Englewood Cliffs, Prentice-Hall, Inc.

Dwiyanto, Agus, dkk. (2002), Reformasi Birokrasi Publik di Indonesia, Yogyakarta: Gadjah Mada University Press.

Hutahaean, Marlan. (2006). “Penataan Kelembagaan, Perubahan Paradigma dan Pilihan

Kebijakan sebagai Langkah Strategis Menanggulangi Kemiskinan: Perspektif Administrasi Publik." Jurnal Kebijakan dan Administrasi Publik (JKAP), Volume 10, Nomor 1 (Mei 2006), TERAKREDITASI DIKTI.

(2008). Pengantar Studi Kebijakan Publik. Bandung: Pustaka Sutra.

(2013). "Transaksi Fee" Pada Dinamika Terbentuknya Pemerintahan Divided atau Unified di Kota Pematangsiantar: Studi Kasus Pembuatan Kebijakan Anggaran Pendapatan dan Belanja Daerah 2005-2010. Disertasi (Tidak Dipublikasikan). Yogyakarta: Program Pasca Sarjana, Program Pendidikan Doktor Administrasi Publik, Fakultas Ilmu Sosial dan Ilmu Politik, Universitas Gadjah Mada.

Jazairy, Idris, et.al. (1992). The State of World Rural Poverty: An Inquiry into Its Causes and Concequencies. USA: New York University Press.

Jones, C. O. (1984). An Introduction to The Study of Public Policy. $3^{\text {rd }}$ Ed. Monterey, California: Brooks/Cole Publishing Company.

Keban, Y. T. (1995). Pengantar Administrasi Publik. Yogyakarta: Porgram Pasca Sarjana Magister Administrasi Publik, Universitas Gadjah Mada.

Kuncoro, Mudrajad. (2004). Otonomi dan Pembangunan Daerah: Reformasi, Perencanaan Strategi dan Peluang. Jakarta: Erlangga.

Lester, J. and Stewart, J. Jr. (2000). Public Policy: An Evolutionary Approach. Belmont, CA: Wadsworth.

Lindblom, C. E. (1980). The Policy Making Process. New Jersey: Prentice-Hall, Englewood Cliffs. 
Mas'udi Wawan \& Ley, Cornelis (eds.) (2018). Politik Kesejahteraan: Kontestasi Rezim Kesejahteraan di Indonesia, Jakarta: Yayasan Obor Indonesia bekerja sama dengan PolGov Fisipol UGM dan Universitas Oslo, Norwegia.

Manalu, Dimpos. (2004), “Agenda Pengentasan Kemiskinan Pasca Otonomi Daerah di Sumatera Utara" (policy brief tidak diterbitkan), Yogyakarta: UGM, 13766/PS/MSK/20.

Parsons, Wayne. (2005). Public Policy: Pengantar Teori dan Praktik Analisis Kebijakan, Jakarta: Kencana.

Patton, M. Q. (2002). Qualitative Research and Evaluation Methods. $3^{\text {rd }}$ Ed. Thousand Oaks: Sage Publications.

Sinurat, Rajaipan. 2020. Makalah. Balige: Dinas Sosial-tidak dipublikasikan

Sumarto, Mulyadi. (2014), Perlindungan Sosial dan Klientelisme: Makna Politik Bantuan Tunai dalam Pemilihan Umum, Yogyakarta: Gadjah Mada University Press.

Tjokrowinoto, Moeljarto. (1995). Teori Pembangunan. Yogyakarta: Program Pasca Sarjana, Magister Administrasi Publik, Universitas Gadjah Mada.

Wibawa, Samodra. (1992). “Proses Pembuatan Kebijaksanaan Publik: Kasus Lokal di Indonesia. Laporan Penelitian. Yogyakarta: Fakultas Ilmu Sosial dan Ilmu Politik, Universitas Gadjah Mada.

Yin, R. K. (2003). Case Study Research Design and Methods. $3^{\text {rd }}$ Ed. Thousand Oaks: Sage Publications.

\section{Dokumen Lain:}

Kabupaten Toba Dalam Angka 2020, Balige: BPS Kabupaten Toba.

Kompas, 30 Mei 2020.

Peraturan Pemerintah Nomor 43 Tahun 2004 tentang Pelaksanaan Upaya Peningkatan Kesejahteraan Lanjut Usia.

Peraturan Pemerintah Nomor 39 Tahun 2012 tentang Penyelenggaraan Kesejahteraan Sosial.

Peraturan Pemerintah Nomor 70 Tahun 2019 tentang Perencanaan, Penyelenggaraan, Evaluasi terhadap Penghormatan, Perlindungan dan Pemenuhan Hak Penyandang Disabilitas

Peraturan Pemerintah No. 14 Tahun 2020 tentang Perubahan Nama Kabupaten Toba Samosir Menjadi Kabupaten Toba 
Risalah Rapat Rancangan Peraturan Daerah tentang Penyelenggaraan Kesejahteraan Sosial di Kabupaten Toba.

Risalah Rapat Rancangan Peraturan Daerah tentang Perlindungan dan Pemenuhan Hak Penyandang Disabilitas di Kabupaten Toba.

Risalah Rapat Rancangan Peraturan Daerah tentang Penyelenggaraan Kesejahteraan Lanjut Usia di Kabupaten Toba

Undang-undang Nomor 7 Drt Tahun 1956 tentang Pembentukan Daerah Otonom KabupatenKabupaten dalam Lingkungan Propinsi Sumatera Utara.

Undang-Undang Nomor 13 Tahun 1998 tentang Kesejahteraan Lanjut Usia

Undang-Undang Nomor 36 Tahun 2003 tentang Pembentukan Kabupaten Samosir dan Kabupaten Serdang Bedagai, dan Kabupaten Samosir.

Undang-Undang Nomor 11 Tahun 2009 tentang Kesejahteraan Sosial.

Undang-Undang Nomor 12 Tahun 2011 tentang Pembentukan Peraturan Perundangundangan.

Undang-Undang Nomor 23 Tahun 2014 tentang Pemerintahan Daerah.

Undang-Undang Nomor 8 Tahun 2016 tentang Penyandang Disabilitas

URL:

https://www.liputan6.com/regional/read/4195978/kabupaten-toba-samosir-berganti-namamenjadi-toba, diakses 16 Mei 2020.

https://news.detik.com/berita/d-4923096/jokowi-teken-perubahan-nama-kabupaten-tobasamosir-jadi-toba, diakses 16 Mei 2020.

https://medan.tribunnews.com/2020/03/05/kabupaten-toba-samosir-resmi-beralih-nama-jadikabupaten-toba-identitas-ktp-lama-tetap-berlaku, diakses 16 Mei 2020.

https://id.wikipedia.org/wiki/Kabupaten_Toba\#Suku, diakses 24 Mei 2020.

https://nasional.tempo.co/read/704350/rasio-guru-murid-indonesia-lampaui-singapuratapi/full\&view=ok, diakses 24 Mei 2020.

https://www.beritasatu.com/nasional/273803-acdp-rasio-guru-dan-murid-di-indonesiatimpang, diakses 24 Mei 2020.

http://documents.worldbank.org/curated/en/704271468044660179/pdf/741550BRI0INDO00B ox377384B00PUBLIC0.pdf, diakses 24 Mei 2020. 
https://ifestyle.kompas.com/read/2016/05/10/093908423/Jumlah.Dokter.di.Indonesia.Cukup. tetapi.Menumpuk.di.Kota.Besar, diakses 18 Mei 2020.

https://irto.id/idi-jumlah-dokter-mencukupi-sistem-distribusinya-belum-optimal-djwT, diakses 18 Mei 2020.

https://ekonomi.bisnis.com/read/20190620/12/935811/indonesia-kebanyakan-dokter-tetapiterpusat-di-kota-besar, diakses 18 Mei 2020.

https://theconversation.com/dokter-menumpuk-di-jawa-dan-kota-akar-masalahnya-padasistem-rekrutmen-dan-pendidikan-kedokteran-122391, diakses 18 Mei 2020.

https://www.bps.go.id/website/materi_ind/materiBrsInd-20200115120531.pdf, diakses 24 Mei 2020.

https://tobasamosirkab.bps.go.id/statictable/2016/08/11/99/gini-ratio-kabupaten-tobasamosir-2001-2015.html, diakses 16 Mei 2020;

https://www.bps.go.id/linkTableDinamis/view/id/1116, diakses 24 Mei 2020.

https://www.bps.go.id/pressrelease/2020/02/05/1755/ekonomi-indonesia-2019-tumbuh-5-02-

persen.html, diakses 30 Mei 2020.

https://difabel.tempo.co/read/1259756/pp-pedoman-pemenuhan-hak-penyandang-

disabilitas-sudah-diketok/full\&view=ok, diakses 31 Mei 2020.

https://nasional.tempo.co/read/243050/jelang-pilkada-dana-bantuan-sosial-tasikmalayameningkat, diakses 31 Mei 2020.

https://tirto.id/anggaran-bantuan-sosial-langganan-naik-saat-tahun-pemilu-dcdb, diakses 31 Mei 2020.

https://www.kppod.org/berita/view?id=425, diakses 31 Mei 2020.

https://www.cnbcindonesia.com/news/20190422174033-4-68067/sebelum-pilpres-

pemerintah-sebar-bantuan-sosial-rp-37-t, diakses 31 Mei 2020.

https://edukasi.kompas.com/read/2015/11/09/18010771/Dana.Bansos.yang.Meningkat.Jelang.

Pilkada.Dikhawatirkan.Rawan.Politik.Uang, diakses 31 Mei 2020.

https://nasional.tempo.co/read/720635/dana-bansos-dan-hibah-meningkat-jelang-pilkada, diakses 31 Mei 2020.

https://news.detik.com/berita/d-3759685/jelang-pilkada-serentak-kpk-ingatkan-inkumbensoal-dana-bansos, diakses 31 Mei 2020. 
https://www.liputan6.com/news/read/2365846/kemendagri-akui-dana-bansos-selalumeningkat-jelang-pilkada, diakses 31 Mei 2020.

https://kumparan.com/kumparannews/dana-bansos-dan-hibah-rawan-diselewengkanpetahana-jelang-pilkada, diakses 31 Mei 2020. 